\title{
Spondias purpurea L. Stem Bark Extract: Antioxidant and in vitro Photoprotective Activities
}

\author{
Francisco Alessandro M. Rodrigues, ${ }^{\oplus a}$ Priscylla S. Giffony, ${ }^{b}$ Sarah B. F. dos Santos, ${ }^{\circledR a}$ \\ Jhonyson A. C. Guedes, ${ }^{\circledR a c}$ Maria Elenir N. P. Ribeiro, ${ }^{\circledR a}$ Tamara G. de Araújo, ${ }^{b}$ \\ Larissa M. R. da Silva, ${ }^{d}$ Guilherme J. Zocolo ${ }^{\circledR c}$ and Nágila M. P. S. Ricardo ${ }^{\circledR * a}$ \\ ${ }^{a}$ Departamento de Química Orgânica e Inorgânica, Universidade Federal do Ceará, \\ Av. Humberto Monte, s/n, Pici, 60455-760 Fortaleza-CE, Brazil \\ ${ }^{b}$ Departamento de Farmácia, Universidade Federal do Ceará, Campus Porangabussu, \\ 60430-170 Fortaleza-CE, Brazil \\ 'Embrapa Agroindústria Tropical, Rua Dra. Sara Mesquita, 2270, Pici, \\ 60020-181 Fortaleza-CE, Brazil \\ ${ }^{d}$ Departamento de Engenharia de Alimentos, Universidade Federal do Ceará, \\ Av. Humberto Monte, s/n, Pici, 60020-181 Fortaleza-CE, Brazil
}

\begin{abstract}
Plant phenolic extracts are widely recognized as an important source of natural antioxidant substances and potential compounds for cosmetic formulations. This study aimed to evaluate the chemical profile, photoprotective and antioxidant activities of stem bark extract of Spondias purpurea L. (ciriguela) and its application in photoprotective formulations. Thirty phenolic constituents were annotated by ultra-performance liquid chromatography coupled with an electrospray ionization quadrupole time-of-flight mass spectrometry in mode negative (UPLC-QTOF-MS ${ }^{2}$ ). The stem bark extract antioxidant and chelation potential, expressed in half maximal inhibitory concentration $\left(\mathrm{IC}_{50}\right.$ ), showed 6.25 and $352.22 \mu \mathrm{g} \mathrm{mL} \mathrm{m}^{-1}$, respectively. The phenolic extract was used as an active ingredient in six sunscreen formulations, with concentrations ranging from 0.2 to $10 \%$. The ultraviolet (UV) protection properties of the formulations were evaluated by sun protection factor (SPF) values obtained in $0.2 \mathrm{mg} \mathrm{mL}-1$ ( 0.495 to 2.27 ) and $2.0 \mathrm{mg} \mathrm{mL}^{-1}$ (2.29 to 15.87 ). The SPF value for the extract (14.37 and 26.16) was high, but there was a reduction in the base formulation. However, these results suggested that the bioactive extracted of stem bark of Spondias purpurea L. has interesting potential to reduce the damage caused by UV radiation and may be utilized as an active ingredient in a sunscreen formulation.
\end{abstract}

Keywords: ciriguela, UPLC-QTOF-MS² profile, sunscreen formulation, stem bark extract

\section{Introduction}

Skin neoplasms are one of the highest incidences worldwide form of cancer and globally represent $7.35 \%$ of all cancer cases in 2018, according to Ferlay et al. ${ }^{1}$ Melanoma and non-melanoma type represented 1.04 million and 28.7 thousand of cases in all world, respectively. The main cause of skin cancer is prolonged exposure to solar ultraviolet (UV) radiation. ${ }^{2}$

Prolonged exposure to UV radiation causes physical changes to the skin, at the tissue or cellular level. Besides, it has a high carcinogenic potential with

*e-mail: naricard@ufc.br direct action on both deoxyribonucleic acid (DNA) and proteins; and indirectly, it induces the formation of several reactive oxygen species (ROS) ${ }^{3,4}$ ROS can induce lipid peroxidation, mitochondrial damage, and changes in the structure of nucleic acids, proteins, and genes. ${ }^{5}$ Furthermore, skin exposed to UV radiation is susceptible to the appearance of photoallergies, erythema, accelerated skin photoaging, and the development of skin neoplasms. ${ }^{2,4,6}$

The daily application of sunscreen products is highly recommended for photoaging prevention, sunburns, and the appearance of skin cancer. ${ }^{7}$ Most photoprotection filter formulations are composed of chemical agents, organic or inorganic, which absorb, filter, disperse, and reflect the 
radiation UV. ${ }^{6,8}$ However, these conventional formulations can be photounstable, reducing their effectiveness and generating by-products that can cause phototoxicity and photoallergic reactions. ${ }^{9,10}$

Many studies ${ }^{2,3}$ have demonstrated the photoprotective action of polyphenolic compounds due to their broad spectrum of UV absorption and antioxidant properties that protect cells from oxidative stress. Phenolic compounds are secondary metabolites that have relevant antioxidant properties related to their chemical structure, such as conjugation potential, the number of aromatic rings, and the position of hydroxyl and other functional groups. These compounds are multifunctional antioxidants that can break the chain reaction (free radical scavengers) and to chelate metal ions such as iron and copper, inhibiting the oxidation of low-density lipoproteins. ${ }^{5,6,11}$

Research in cosmetic and phytocosmetic formulations, using phenolic extracts obtained from plants, have shown UV photoprotection potential, erythema suppression, powerful free radical removal effect, among other synergistic properties. ${ }^{2,6,8}$ Anacardiaceae family is rich in secondary metabolites such as phenolic compounds with interesting biological activities. ${ }^{12,13}$ Spondias purpurea $\mathrm{L}$. is a medium-sized tree of the Anacardiaceae family, and their fruits (ciriguela) and other aerial parts generally have many polyphenolic compounds, such as flavonoids, tannins, anthocyanidins, catechins, epicatechins, as well as other non-volatile and volatile compounds. ${ }^{14,15}$ Some studies have reported the chemical profile of fruits ${ }^{12}$ and the photoprotective and antioxidant action of phenolic extracts of Spondias purpurea L. fruits peel. ${ }^{4}$ However, little is known about the chemical compounds present in the stem bark of this species.

In the present study, innovative sunscreen formulations containing stem bark phenolic extract of Spondias purpurea L. were prepared, aiming to reduce the synthetic organic filter concentration without compromising the photoprotective efficacy. The hypothesis that this phenolic extract could act as constituents of photoprotective formulations was evaluated through their in vitro antioxidant and photoprotective action and the identification of the presence of polyphenol compounds. Besides, formulations containing different content of Spondias purpurea L. stem bark extract and formulation with just the commercial filter were investigated to assess their photoprotective activity and synergistic action. It is important to highlight that, at the best of our knowledge, there is no other work about the development of the sunscreen products containing Spondias purpurea L. stem bark extract.

\section{Experimental}

\section{Chemical}

Cetearyl alcohol, lecithin, cetearyl glycoside, octyl methoxycinnamate, and methylparaben were purchased from Mapric (São Paulo, Brazil). The ethylenediaminetetraacetic acid (EDTA) and isopropyl palmitate were purchased from Infinity Pharma (Campinas, Brazil). Propylene glycol and aminomethyl propanol were purchased from Hallstar (Chicago, USA) and Fragon (São Paulo, Brazil), respectively. Ascorbic acid and gallic acid were obtained from Sigma-Aldrich (Saint Louis, USA). Aluminum chloride hexahydrate and sodium acetate were purchased from Vetec (Duque de Caxias, Brazil) and Synth (Diadema, Brazil) respectively. The 2,2-diphenyl-1-picrylhydrazyl (DPPH), 3-(2-pyridyl) 5,6-diphenyl-1,2,4-triazine$p$ - $p$ '-disulfonic acid (ferrozine), Folin-Ciocalteu reagent, sodium carbonate, ferrous sulfate, and all solvents used were purchased from Sigma-Aldrich (Saint Louis, USA). For all methods, high purity water by Milli-Q system (Bedford, USA) was used.

\section{Plant materials}

Stem bark samples of Spondias purpurea L. were collected in the municipality of Ararendá, Ceará, Brazil $\left(4^{\circ} 45^{\prime} 18.0^{\prime \prime} \mathrm{S} 40^{\circ} 49^{\prime} 41.3^{\prime \prime} \mathrm{W}\right)$ and the use of these species was registered in the Brazilian National System of Management of Genetic Heritage and Associated Traditional Knowledge (SisGen) by registration number A53C3CE. The specimen was deposited in the Prisco Bezerra Herbarium (EAC) located at the Federal University of Ceará. Stem barks samples were dry at $20{ }^{\circ} \mathrm{C}$ for seven days and crushed into smaller sizes.

\section{Stem bark extract (SBE)}

The phenolics were extracted by macerating the dried material (each batch with $5 \mathrm{~g}$ of stem bark and $300 \mathrm{~mL}$ of $70 \%$ (v/v) ethanolic solution) under constant agitation (400 rpm for $48 \mathrm{~h}$ ). The crude hydroethanolic extract was concentrated in a rotary evaporator at $45{ }^{\circ} \mathrm{C}$ and filtered through $0.28 \mu \mathrm{m}$ filter paper and freeze-dried.

\section{Total phenolic content (TPC)}

The total phenolic was determined by the FolinCiocalteu method. ${ }^{16}$ An aliquot $(0.025 \mathrm{~mL})$ of the hydroethanolic extract solution $\left(1 \mathrm{mg} \mathrm{mL}^{-1}\right)$ was diluted to $0.5 \mathrm{~mL}$ and mixed with $0.5 \mathrm{~mL}$ of Folin-Ciocalteu reagent, 
$1.0 \mathrm{~mL}$ of $20 \% \mathrm{~m} / \mathrm{v}$ sodium carbonate $\left(\mathrm{Na}_{2} \mathrm{CO}_{3}\right)$, and $1.0 \mathrm{~mL}$ of distilled water. The mixture was vortexed and left to stand for $30 \mathrm{~min}$ at room temperature and out of the reach of light. Absorbance was then measured at $700 \mathrm{~nm}$ using the spectrophotometer (Genesys 10S, Thermo Scientific, USA). Gallic acid (10-50 $\left.\mu \mathrm{g} \mathrm{mL}^{-1}\right)$ was used in the construction of the standard curve $(y=0.0156 x+0.0073$, with coefficient of determination $\left(r^{2}\right)$ equal to 0.9995$)$. The values (triplicate) were expressed in terms of milligrams of gallic acid equivalents (mg GAE) per gram extract.

\section{Total flavonoid content (TFC)}

The total flavonoid content was determined according to the aluminum chloride colorimetric method described by Lin and Tang. ${ }^{17}$ Briefly, aliquots of SBE solution $(0.5 \mathrm{~mL})$ was mixed with $1.5 \mathrm{~mL}$ of $95 \%$ ethanol, $0.1 \mathrm{~mL}$ of $10 \% \mathrm{~m} / \mathrm{v}$ aluminum chloride hexahydrate $\left(\mathrm{AlCl}_{3} \cdot 6 \mathrm{H}_{2} \mathrm{O}\right), 0.1 \mathrm{~mL}$ of $1 \mathrm{~mol} \mathrm{~L}^{-1}$ sodium acetate $\left(\mathrm{CH}_{3} \mathrm{COONa}\right)$, and $2.8 \mathrm{~mL}$ of deionized water. After $40 \mathrm{~min}$ at room temperature, the reaction mixture absorbance was measured at $415 \mathrm{~nm}$ against a deionized water blank on a spectrophotometer (Genesys 10S, Thermo Scientific, USA). Quercetin $\left(0-100 \mu \mathrm{g} \mathrm{mL}^{-1}\right)$ was used in the construction of the standard curve $\left(y=0.001 x+0.007, \mathrm{r}^{2}=0.9988\right)$. The data (triplicate) were expressed as milligram quercetin equivalents (QE) $100 \mathrm{~g}^{-1} \mathrm{SBE}$.

\section{$\mathrm{DPPH} \bullet$ radical scavenging assay}

The antioxidant activity of SBE was investigated by the $\mathrm{DPPH}^{\bullet}$ radical scavenging assay. The solution of SBE in ethanol was prepared at concentrations in the range of $1-250 \mu \mathrm{g} \mathrm{mL}^{-1} .2 .5 \mathrm{~mL}$ of each concentration were mixed with $1.0 \mathrm{~mL}$ of $0.3 \mathrm{mmol} \mathrm{L}{ }^{-1} \mathrm{DPPH}$-ethanol solution, at room temperature, and in the dark for $30 \mathrm{~min}$. Afterward, the absorbance was measured at $518 \mathrm{~nm}$ in a UV-Vis spectrophotometer (Genesys 10S, Thermo Scientific, USA). The blank solution was composed of ethanol. The SBE antioxidant activity was evaluated in comparison with ascorbic acid and expressed as half maximal inhibitory concentration $\left(\mathrm{IC}_{50}\right)$ value. The ability of the test sample to scavenge the $\mathrm{DPPH}^{\bullet}$ radical was calculated using the following equation 1 :

$\mathrm{DPPH}^{\cdot}$ scavenging rate $(\%)=\frac{\left(\mathrm{A}_{\mathrm{c}}-\mathrm{A}_{\mathrm{s}}\right)}{\mathrm{A}_{\mathrm{c}}} \times 100$

where $A_{c}$ was the absorbance of the control and $A_{s}$ was the absorbance of the sample with DPPH-ethanol solution.

\section{Ferrous ion chelation (FIC) assay}

FIC assay was carried out by the method of Chew et al. ${ }^{18}$ with some modifications. In this order, $1 \mathrm{~mL}$ of $0.1 \mathrm{mmol} \mathrm{L}^{-1}$ ferrous sulfate $\left(\mathrm{FeSO}_{4}\right)$ was mixed, $1 \mathrm{~mL}$ of the extract solution at concentrations $5,10,25,50,125,250 \mu \mathrm{g} \mathrm{mL}^{-1}$ and $1 \mathrm{~mL}$ of $0.25 \mathrm{mmol} \mathrm{L}^{-1}$ ferrozine (3-(2-pyridyl) 5,6-diphenyl-1,2,4-triazine- $p$ - $p$ '-disulfonic acid). The tubes were vortexed for $1 \mathrm{~min}$. After $10 \mathrm{~min}$, readings were performed on a UV-Vis spectrophotometer (Genesys 10S, Thermo Scientific, USA) at $562 \mathrm{~nm}$. The entire experiment was carried out in triplicate. The same method was performed with the EDTA as a positive control for further analysis and comparison of results. The results were expressed as ferrous ion chelation ability (\%) (equation 2) and $\mathrm{IC}_{50}$.

$\operatorname{FIC}(\%)=\frac{\left(A_{c}-A_{s}\right)}{A_{c}} \times 100$

where $\mathrm{A}_{\mathrm{c}}$ was the absorbance of the control and $\mathrm{A}_{\mathrm{s}}$ was the absorbance of the sample with ferrozine- $\mathrm{FeSO}_{4}$ solution.

Analysis of chemical profile using ultra-performance liquid chromatography coupled with an electrospray ionization quadrupole time-of-flight mass spectrometry (UPLC-QTOF/ $\mathrm{MS}^{\mathrm{E}}$ )

A Waters Acquity ultra performance liquid chromatography (UPLC) equipment coupled to a quadrupole/TOF system (Waters, USA) was used to identify the chemical compounds present in SBE. The UPLC analysis conditions included the use of Waters Acquity UPLC BEH column $(150 \mathrm{~mm} \times 2.1 \mathrm{~mm}, 1.7 \mu \mathrm{m})$ at a fixed temperature of $40{ }^{\circ} \mathrm{C}$. An exploratory gradient using water (A) and acetonitrile (B) (both with $0.1 \%$ formic acid) as mobile phases varying from 2 to $95 \% \mathrm{~B}$ (0-18 $\mathrm{min}$ ), flow rate of $0.4 \mathrm{~mL} \mathrm{~min}{ }^{-1}$ and injection volume of $5 \mu \mathrm{L}$ was the method adopted. The chemical profiles were determined by coupling the Waters ACQUITY UPLC system to a QTOF mass spectrometer (Waters, Milford, USA) with an electrospray ionization interface (ESI) in negative ionization modes. The ESI (-) modes were in the range of 110-1200 Da, with a fixed temperature of $120^{\circ} \mathrm{C}$ and a desolvation gas temperature of $350{ }^{\circ} \mathrm{C}$. Leucine enkephalin was used as a lock mass. The mass spectrometry (MS) mode used Xevo G2-XS QTOF. The spectrometer operated with $\mathrm{MS}^{\mathrm{E}}$ centroid programming using a tension ramp from 20 to $40 \mathrm{~V}$. $10 \mathrm{mg}$ sample of hydroethanolic extract SBE were solubilized in $4 \mathrm{~mL}$ of $80 \%(\mathrm{v} / \mathrm{v})$ solution of methanol and homogenized in a vortex. An aliquot of 
$1 \mathrm{~mL}$ was filtered in a $0.22 \mu \mathrm{m}$ poly(tetrafluoroethene) (PTFE) filter and injected into the system. The acquisition and analysis of data were controlled using MassLynx 4.1 software (Milford, USA). ${ }^{19}$ The compounds were annotated based on their exact mass and comparison with previously published data.

Determination of the spectrophotometric profile of aqueous extract of SBE and octyl methoxycinnamate

Spectrophotometric profile was obtained according to a method adapted from Munhoz et al. ${ }^{20}$ The dry extract was solubilized in water and the UVB filter in ethanol, both at a concentration of 0.2 and $2.0 \mathrm{mg} \mathrm{mL}^{-1}$. Scanning between the wavelengths of 200 and $400 \mathrm{~nm}$ was carried out using a spectrophotometer (Genesys 10S, Thermo Scientific, USA) to verify the absorption in the ultraviolet regions $\mathrm{A}, \mathrm{B}$, and $\mathrm{C}$. The blank solution was composed of water and ethanol, and the experiment was performed in triplicate.

\section{Determination of in vitro sun protection factor (SPF)}

The evaluation of the in vitro UVB photoprotection was carried out using the spectrophotometric method described by Mansur et al. ${ }^{21}$ Mansur's method is simple and easily reproducible. The SPF determination is the correlation between the erythemogenic effect (EE) and the radiation intensity at each wavelength (I) (Table 1). Subsequently, spectrophotometric scanning at wavelengths between 260$400 \mathrm{~nm}$, with intervals of $5 \mathrm{~nm}$ was performed. The readings were performed using quartz cell $(1 \mathrm{~cm})$, and distilled water used as blank. Calculation of SPF was obtained according to the equation 3 .
$\mathrm{SPF}=\mathrm{CF} \times \sum_{290}^{320} \mathrm{EE}_{(\lambda)} \times \mathrm{I}_{(\lambda)} \times \mathrm{Abs}_{(\lambda)}$

where $\mathrm{CF}$ : correction factor (equal to 10 ); $\mathrm{EE}_{(\lambda)}$ : erythematous effect of radiation of wavelengths $(\lambda) ; I_{(\lambda)}$ : intensity of sunlight at wavelength $(\lambda) ; \operatorname{Abs}_{(\lambda)}$ : spectrophotometric absorbance reading for preparing the solution at a wavelength $(\lambda)$.

Table 1. Correlation between the erythemogenic effect (EE) and the radiation intensity at each wavelength $(\mathrm{I})^{21}$

\begin{tabular}{lc}
\hline$\lambda / \mathrm{nm}$ & $\mathrm{EE}_{(\lambda)} \times \mathrm{I}_{(\lambda)}$ \\
\hline 290 & 0.0150 \\
295 & 0.0817 \\
300 & 0.2874 \\
305 & 0.3278 \\
310 & 0.1864 \\
315 & 0.0839 \\
320 & 0.0180 \\
\hline
\end{tabular}

$\overline{\mathrm{EE}_{(\lambda)} \text { : erythematous effect of radiation of wavelengths }(\lambda) ; \mathrm{I}_{(\lambda)} \text { : intensity }}$ of sunlight at wavelength $(\lambda)$.

Preparation of a cosmetic formulation and in vitro SPF determination

Six formulations were prepared (Table 2): base formulation (FB), lotion and extract $0.2 \%\left(\mathrm{FBE}_{0.2}\right), 2.5 \%$ $\left(\mathrm{FBE}_{2.5}\right), 5 \%\left(\mathrm{FBE}_{5}\right), 10 \%\left(\mathrm{FBE}_{10}\right)$; base formulation and octyl methoxycinnamate $7.5 \%\left(\mathrm{FBOM}_{7.5}\right)$; and base formulation, extract $10 \%$ and octyl methoxycinnamate $7.5 \%\left(\mathrm{FBE}_{10} \mathrm{OM}_{7.5}\right)$. The UVB photoprotection of the formulations was measured according to the previous description. A sample solution was obtained ( 0.2 and $2.0 \mathrm{mg} \mathrm{mL}^{-1}$ ) and FB was used as blank.

Table 2. Composition of formulations prepared for the photoprotective assay

\begin{tabular}{|c|c|c|c|c|c|c|c|}
\hline Component & FB & $\mathrm{FBE}_{0.2}$ & $\mathrm{FBE}_{2.5}$ & $\mathrm{FBE}_{5}$ & $\mathrm{FBE}_{10}$ & $\mathrm{FBOM}_{7.5}$ & $\mathrm{FBE}_{10} \mathrm{OM}_{7.5}$ \\
\hline Cetearyl alcohol / wt. $\%$ & 0.5 & 0.5 & 0.5 & 0.5 & 0.5 & 0.5 & 0.5 \\
\hline Lecithin and cetearyl glycoside / wt. \% & 1.0 & 1.0 & 1.0 & 1.0 & 1.0 & 1.0 & 1.0 \\
\hline Isopropyl palmitate / wt.\% & 3.0 & 3.0 & 3.0 & 3.0 & 3.0 & 3.0 & 3.0 \\
\hline Propylene glycol / wt.\% & 2.0 & 2.0 & 2.0 & 2.02 & 2.0 & 2.0 & 2.0 \\
\hline Methylparaben / wt.\% & 0.05 & 0.05 & 0.05 & 0.05 & 0.05 & 0.05 & 0.05 \\
\hline Propylparaben / wt.\% & 0.015 & 0.015 & 0.015 & 0.015 & 0.015 & 0.015 & 0.015 \\
\hline Octyl methoxycinnamate / wt. $\%$ & - & - & - & - & - & 7.5 & 7.5 \\
\hline SBE of S. purpurea / wt. $\%$ & - & 0.2 & 2.5 & 5.0 & 10 & - & 10 \\
\hline EDTA / wt. \% & 0.05 & 0.05 & 0.05 & 0.05 & 0.05 & 0.05 & 0.05 \\
\hline Aminomethyl propanol / wt.\% & q.s. & q.s. & q.s. & q.s. & q.s. & q.s. & q.s. \\
\hline Water / wt.\% & q.s. & q.s. & q.s. & q.s. & q.s. & q.s. & q.s. \\
\hline
\end{tabular}

FB: base formulation; FBE: base formulation with extract; OM: octyl methoxycinnamate; SBE: stem bark extract; EDTA: ethylenediaminetetraacetic acid; q.s.: quantum sufficit. 


\section{Statistical analysis}

All experimental data were represented as mean \pm standard deviation (SD). Statistical values were assessed by using the Minitab ${ }^{\circledR}$ software ${ }^{22}$ with a one-way analysis of variance (ANOVA), $p<0.05$ expected to indicate statistical significance.

\section{Results and Discussion}

Phenolic, flavonoid content and antioxidant and chelating activity

Polyphenols are secondary plant metabolites and have several potentially beneficial bioactive functions for humans, such as antimutagenic, anticarcinogenic, and antioxidant activity, already reported in the literature. ${ }^{11}$ Several studies ${ }^{4,23-26}$ have shown the high phenolic content in leaves, fruits, fruit peel, and stem bark of species of the Anacardiaceae family.

In this study, the total phenolics content determined in SBE was $523.26 \pm 18.11 \mathrm{mg} \mathrm{GAE} \mathrm{g}^{-1}$ (Table 3). This result suggests a higher content of phenolic compounds present in stem bark compared to other aerial parts of the Spondias purpurea L. such as fruit pulp and epicarp. ${ }^{4,26}$ Silva et al. ${ }^{4}$ found a lower total phenolic value, $28.68 \pm 0.05 \mathrm{mg} \mathrm{GAE} \mathrm{g}^{-1}$, in the methanolic extract from the peel of Spondias purpurea L. fruit. Santos et al. ${ }^{24}$ also found a high value for stem bark hydroethanolic extracts (403.26 mg GAE $\mathrm{g}^{-1}$ ) for Schinopsis brasiliensis bark extract, which also belongs to the Anacardiaceae family.

TFC of SBE is shown in Table 3. In general, the content of total flavonoids was low in SBE sample. This result suggests that flavonoids do not contribute strongly to antioxidant capacity of SBE. Villa-Hernández et al. ${ }^{26}$ evaluated the flavonoid content in $S$. purpurea fruit (epicarp and pulp) and also found a lower value (2.4-4.7 $\left.\mu \mathrm{g} \mathrm{g}^{-1}\right)$ when compared to the total phenolic content.

This study analyzed the antioxidant and chelating activity of Spondias purpurea L. stem bark hydroethanolic extract using the $\mathrm{DPPH}^{\bullet}$ and ferrous ion chelation method (Table 3 and Figure S1, Supplementary Information (SI) section). The SBE exhibited a scavenging activity of the $\mathrm{DPPH}^{\bullet}$ radical very efficient when compared with ascorbic acid, used in this work as standard. The results of inhibition of the radical can be seen in Table 3. One way to measure the inhibition capacity of the $\mathrm{DPPH}^{\bullet}$ radical is by calculating the $\mathrm{IC}_{50}$. The $\mathrm{IC}_{50}$ is the necessary concentration of the antioxidant to reduce the $\mathrm{DPPH}^{*}$ radical by $50 \%$ and decreasing values indicate higher antioxidant activity. The SBE test resulted in an $\mathrm{IC}_{50}$ of $6.25 \pm 0.52 \mu \mathrm{g} \mathrm{mL}{ }^{-1}$ (Table 3), which is close to that found for ascorbic acid with an $\mathrm{IC}_{50}$ of $9.85 \pm 1.65 \mu \mathrm{g} \mathrm{mL}^{-1}$ (positive control). Also, the value of $\mathrm{IC}_{50}$ for $\mathrm{SBE}$ was higher than that found by Silva et al. ${ }^{4}$ with $\mathrm{IC}_{50}$ of $27.11 \mu \mathrm{g} \mathrm{mL} \mathrm{mL}^{-1}$ for peels of Spondias purpurea L. The high antioxidant activity presented can be linked to the high content of phenolic compounds present in SBE.

Chelating agents have a significant action as secondary antioxidants because they reduce the redox potential, thereby stabilizing the metal ion's oxidized form. ${ }^{27}$ The chelating activity measured to the phenolic extract against $\mathrm{Fe}^{2+}$ ions showed a lower chelation ability than EDTA (considered a powerful chelating agent). The results showed a chelation ability of $43.57 \pm 0.95 \%$ and an $\mathrm{IC}_{50}$ of $352.22 \pm 15.01 \mu \mathrm{g} \mathrm{mL} \mathrm{m}^{-1}$ for SBE of Spondias purpurea $\mathrm{L}$. stem bark. In general, lower metal chelations are observed for phenolic compounds than EDTA. ${ }^{18,27}$ However, phenolic compounds are shown to be potential sources of natural chelating agents of metallic oxidants. Thus, SBE of Spondias purpurea L. may well be used as a source of the secondary antioxidant agent.

\section{Characterization of phytochemical profiles}

UPLC-QTOF-MS ${ }^{2}$ analysis was carried out to annotated and compare the major chemical components present in the stem bark extract of Spondias purpurea L. ${ }^{28}$ Table 4 shows 30 phytochemical compounds have been annotated, mainly phenolic compounds: phenolic acids, flavonoids (flavonols, flavan-3-ols, and flavanonols), tannins, and their derivatives, benzophenones, and others. The base peak chromatography in negative ionization mode is shown in Figure 1, and the structural proposed of each compound was inferred according to the detected $m / z$, error

Table 3. Polyphenols, flavonoids and antioxidant activity in Spondias purpurea stem bark extracts

\begin{tabular}{|c|c|c|c|c|c|c|}
\hline \multirow{2}{*}{ Sample } & \multirow{2}{*}{$\begin{array}{c}\text { TPC / } \\
\left(\mathrm{mg} \mathrm{GAE} \mathrm{g}^{-1}\right) \\
\end{array}$} & \multirow{2}{*}{$\begin{array}{c}\text { TFC / } \\
\left(\mathrm{mg} \mathrm{QE} 100 \mathrm{~g}^{-1} \mathrm{SBE}\right)\end{array}$} & \multicolumn{2}{|c|}{ DPPH' $^{*}$ assay $^{\mathrm{a}}$} & \multicolumn{2}{|c|}{ FIC assay $^{\mathrm{a}}$} \\
\hline & & & $\mathrm{IC}_{50} /\left(\mu \mathrm{g} \mathrm{mL}^{-1}\right)$ & $\mathrm{RSA} / \%$ & $\mathrm{IC}_{50} /\left(\mu \mathrm{g} \mathrm{mL}^{-1}\right)$ & $\mathrm{CA} / \%$ \\
\hline SBE & $523.26 \pm 18.11$ & $40.2 \pm 4.21$ & $6.25 \pm 0.52$ & $96.57 \pm 0.9$ & $352.22 \pm 15.01$ & $43.57 \pm 0.95$ \\
\hline
\end{tabular}

The test concentrations ranged from 5 to $250 \mu \mathrm{g} \mathrm{mL}{ }^{-1}$; data are described as mean \pm standard deviation $(\mathrm{SD})$, $\mathrm{n}=3$. TPC: total phenolics content; TFC: total flavonoids content; GAE: gallic acid equivalent; QE: quercetin equivalent; SBE: stem bark extract; $\mathrm{IC}_{50}$ : half maximal inhibitory concentration; DPPH: 2,2-diphenyl-1-picrylhydrazyl; FIC: ferrous ion chelation; RSA: radical scavenging activity; CA: chelation ability. 


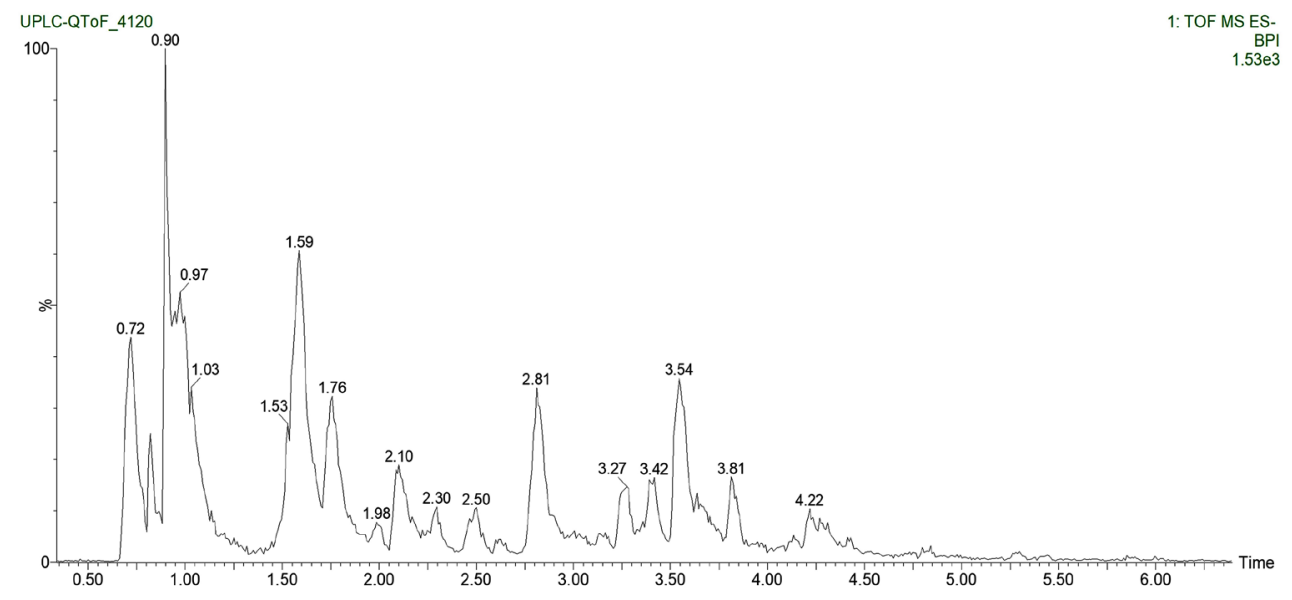

Figure 1. The chromatogram obtained in the UPLC-QTOF-MS in negative mode (ESI-) of the stem bark extracts from the Spondias purpurea L.

(ppm), calculated molecular formula, and obtained $\mathrm{MS}^{2}$ fragment ions (Table 4). The compounds were annotated and characterized by comparing MS and $\mathrm{MS}^{2}$ spectra, together with the fragmentation mechanism, reference data related to family (Anacardiaceae), genus (Spondias), and species (S. purpurea L.), and the SciFinder, ScienceDirect, ChemSpider, PubChem databases, and Human Metabolome databases.

\section{Simple phenolic acids and derivatives}

In this study, five simple phenolic acids were annotated. The peak 4 gave ion $[\mathrm{M}-\mathrm{H}]^{-}$at $\mathrm{m} / z 169.0137$ and a $\mathrm{MS}^{2}$ fragment ion at $\mathrm{m} / \mathrm{z} 125.0252$, resulted from the cleavage of $-\mathrm{CO}_{2}$ group. These fragments are typical of gallic acid. ${ }^{12}$ Peaks $16\left([\mathrm{M}-\mathrm{H}]^{-} m / z, 183.0293\right), 26$ $\left([\mathrm{M}-\mathrm{H}]^{-} \mathrm{m} / \mathrm{z}\right.$ 321.0249) and $27\left([\mathrm{M}-\mathrm{H}]^{-} \mathrm{m} / z\right.$ 197.0452) were annotated as methyl gallate $\left(\mathrm{C}_{8} \mathrm{H}_{8} \mathrm{O}_{5}\right)$, digallic acid $\left(\mathrm{C}_{14} \mathrm{H}_{10} \mathrm{O}_{9}\right)$, and ethyl gallate $\left(\mathrm{C}_{9} \mathrm{H}_{10} \mathrm{O}_{5}\right)$, respectively. The common $\mathrm{MS}^{2}$ fragment ion at $\mathrm{m} / z .169 .01$ in methyl gallate and digallic acid resulting from the fragment of galloyl unit. ${ }^{29-32}$ Peak 16 (methyl gallate) shown $\mathrm{MS}^{2}$ fragment at $\mathrm{m} / z 124.0053\left[\mathrm{M}-\mathrm{H}-\mathrm{CO}_{2} \mathrm{CH}_{3}\right]^{-}$and 168.0013 $\left[\mathrm{M}-\mathrm{H}-\mathrm{CH}_{3}\right]^{-}$. In the ethyl gallate (peak 27) the loss of 28 Da to $\mathrm{m} / \mathrm{z} 169.0132$ was attributable to the neutral loss of ethylene. ${ }^{31,33}$ Another simple phenolic (peak 8), associated with hexoside, was annotated as dihydroxybenzoic acid hexoside. The spectrum mass showed deprotonated ion $\mathrm{m} / z, 315.0718$ and $\mathrm{MS}^{2}$ fragment 153.0193, related to the loss of monosaccharide unit (-162 Da) ${ }^{12}$

\section{Hydrolysable tannins}

Peaks 3, 5, 12, 18 and 25 were annotated as hydrolysable tannins. Peak $\mathbf{3}$ presented precursor ion $[\mathrm{M}-\mathrm{H}]^{-}$at $\mathrm{m} / z 331.0663$ and $\mathrm{MS}^{2}$ spectrum observed the fragments ions at $m / z 271.0386\left[\mathrm{M}-\mathrm{H}-\mathrm{CO}_{2} \mathrm{CH}_{3}\right]^{-}$, and 169.0144 and 125.0292 related to the typical loss of galloyl and carboxylic group, respectively (Figure S2, SI section). This compound $\mathbf{3}$ was annotated as monogalloyl glucose according to previous work. ${ }^{12,24,31}$ The peak 5 showed a deprotonated ion $[\mathrm{M}-\mathrm{H}]^{-}$at $\mathrm{m} / \mathrm{z}, 493.1192$ and yielded fragment ions at $\mathrm{m} / \mathrm{z}, 331.0661$ [M $-\mathrm{H}-162]^{-}$(due to the loss of monosaccharide unit), $241.0650[\mathrm{M}-\mathrm{H}-252]^{-}$and $271.0373[\mathrm{M}-\mathrm{H}-222]^{-}$ caused by cross-ring fragmentations of glucose,$^{34}$ and 169.0133 attributable to the loss of a glucosyl moiety. This compound was annotated as monogalloyl di-glucose $\left(\mathrm{C}_{19} \mathrm{H}_{26} \mathrm{O}_{15}\right)$, according to the report of Cunha et al. ${ }^{35}$ and Dorta et al. ${ }^{31}$ At peak 12, the precursor ion $[\mathrm{M}-\mathrm{H}]^{-}$ $\mathrm{m} / \mathrm{z} 483.0777$ was observed and fragment ions at $\mathrm{m} / \mathrm{z}$ 331.0714 [M - H - 162] $]^{-}, 271.0532[\mathrm{M}-\mathrm{H}-212]^{-}$, $313.0634[\mathrm{M}-\mathrm{H}-170]^{-}$and 169.0132. The compound 12 was annotated as digalloyl glucose. ${ }^{29-32,35}$

Peak 18 showed ion $[\mathrm{M}-\mathrm{H}]^{-} \mathrm{m} / \mathrm{z} 635.0892$ and $\mathrm{MS}^{2}$ fragments ions at $\mathrm{m} / \mathrm{z} 483.0891[\mathrm{M}-\mathrm{H}-152]^{-}$(loss of a galloyl unit from a gallate ester), $465.0908[\mathrm{M}-\mathrm{H}-170]^{-}$, loss of a gallic acid) and 169.0121 (Figure 2). This fragmentation pattern for trigalloyl glucose was previously reported in the literature. ${ }^{29,34}$ Another compound (peak 25) was annotated as tetra- $O$-galloyl hexoside $\left(\mathrm{C}_{34} \mathrm{H}_{28} \mathrm{O}_{22}\right)$ based in research of Abu-Reidah et al..$^{29}$ and Muccilli et al.$^{34}$ This peak 25 showed ion $[\mathrm{M}-\mathrm{H}]^{-}, m / z, 787.0999$ and $\mathrm{MS}^{2}$ fragments in $m / z 635.1156[\mathrm{M}-\mathrm{H}-152]^{-}$, deriving from the loss of a galloyl unit, and $\mathrm{m} / z .169 .0118 .^{34}$

\section{Flavonoid derivatives}

Flavonoids and their glycosides are one of the major classes of compounds annotated in Spondias purpurea L. ${ }^{12}$ A total of 11 flavonoid derivatives were detected in SBE sample. 
Peak $6\left([\mathrm{M}-\mathrm{H}]^{-} m / z\right.$ 609.1454) was annotated as rutin $\left(\mathrm{C}_{27} \mathrm{H}_{30} \mathrm{O}_{16}\right)$, showing a $\mathrm{MS}^{2}$ fragments at $\mathrm{m} / z 301.0458$ (quercetin unit) after the loss of two monosaccharide units. ${ }^{29}$ This compound has already been quantified in Spondias tuberosa leaves. ${ }^{36}$ The hexoside derivative of myricetin was annotated at peak $15\left([\mathrm{M}-\mathrm{H}]^{-}\right.$ $\mathrm{m} / \mathrm{z}$ 479.0828) from the $\mathrm{MS}^{2}$ fragmentation pattern reported in the literature. ${ }^{35,37}$ Compound $\mathbf{2 3}$ showed a $\mathrm{MS}^{2}$ fragment ion detected at $\mathrm{m} / z 301.0613[\mathrm{M}-\mathrm{H}-308]^{-}$ concerning to aglycone ion for quercetin, and $\mathrm{m} / \mathrm{z} 271.0435$ $[\mathrm{M}-\mathrm{H}-162]^{-}$which indicates the loss of the unit of monosaccharide..$^{38}$ Therefore, this compound with the molecular formula $\mathrm{C}_{20} \mathrm{H}_{17} \mathrm{O}_{11}$ was annotated proposed to be quercetin pentoside..$^{12,35}$

Ampelopsin and its glycosylated derivatives were annotated at peaks $30\left([\mathrm{M}-\mathrm{H}]^{-} \mathrm{m} / z, 319.0533\right)$ and 28 $\left([\mathrm{M}-\mathrm{H}]^{-} m / z\right.$ 481.0990), respectively. Peak $30\left(\mathrm{C}_{15} \mathrm{H}_{12} \mathrm{O}_{8}\right)$
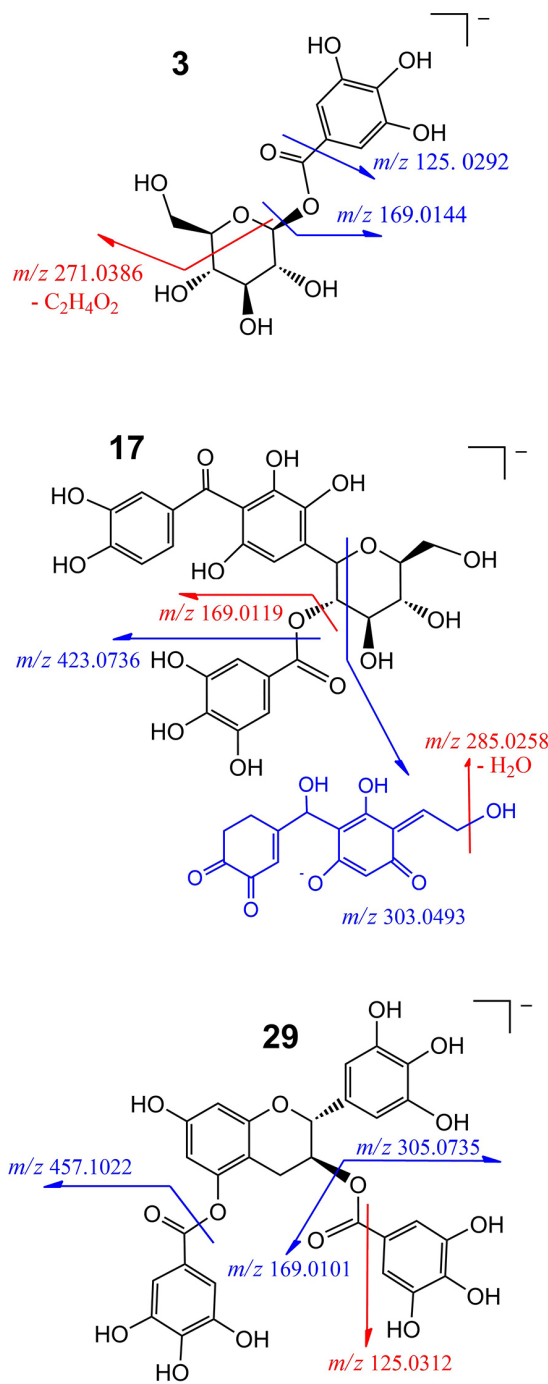

Figure 2. Chemical structures and representative fragmentation in the gas phase of some peak annotation compounds in the stem bark extract of Spondias purpurea L. (adapted from references 31, 34 and 37). showed $\mathrm{MS}^{2}$ fragments at $\mathrm{m} / \mathrm{z} 125.0441,153.1123$, 179.0817, and 193.0112 (Figure S2, SI section) related to aglycone fragmentation of ampelopsin. ${ }^{29}$ Compound $\mathbf{2 8}$ $\left(\mathrm{C}_{21} \mathrm{H}_{22} \mathrm{O}_{13}\right)$ has been annotated assigned as ampelopsin glucoside..$^{29} \mathrm{MS}^{2}$ fragment of this compound has shown the characteristic aglycone ion at $\mathrm{m} / \mathrm{z} 319.0241$ (Figure 2). These substances have numerous pharmacological properties reported as antimicrobial, anti-inflammatory, antioxidant, and anticarcinogenic. ${ }^{39}$

A total of six flavan-3-ols (flavonoid subgroup) and derivatives were annotated at peaks $9, \mathbf{1 1}, \mathbf{1 9}, \mathbf{2 0}, \mathbf{2 4}$, and 29. Peak 11 with precursor ion $[\mathrm{M}-\mathrm{H}]^{-} m / z 593.1296$ was annotated as epicatechin-3,5-O-digallate $\left(\mathrm{C}_{29} \mathrm{H}_{22} \mathrm{O}_{14}\right)$. This compound showed $\mathrm{MS}^{2}$ fragmentation ions $\mathrm{m} / \mathrm{z}$ $441.0632[\mathrm{M}-\mathrm{H}-152]^{-}$, and $289.0535[\mathrm{M}-\mathrm{H}-152]^{-}$ resulted after the successive loss of galloyl unit (152 Da). This fragmentation pattern was previously described by
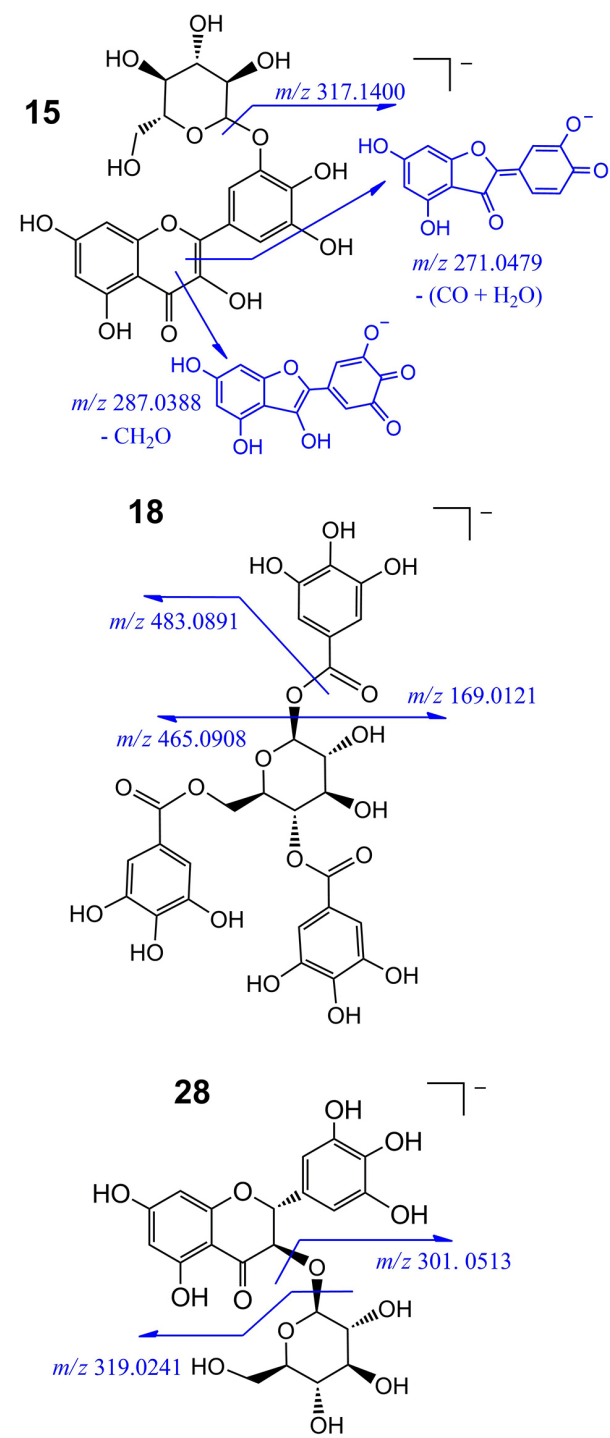
Shoko et al. ${ }^{40}$ for Sclerocarya birrea (Anacardiaceae family). Peak 29 with the molecular formula $\mathrm{C}_{29} \mathrm{H}_{22} \mathrm{O}_{15}$ and having the precursor ion at $m / z, 609.0882$ was being annotated as epigallocatechin-3,5-O-digallate. ${ }^{41}$ In the $\mathrm{MS}^{2}$ spectrum, this compound produced ions fragment at $m / z$ 125.0312, 169.0101, and 457.1022 [M - H - 152 $]^{-}$(Figure 2).

Compounds $9\left(t_{R}=2.27 \mathrm{~min}\right)$ and $19\left(t_{R}=3.54 \mathrm{~min}\right)$ had deprotonated ions $[\mathrm{M}-\mathrm{H}]^{-}$at $\mathrm{m} / \mathrm{z} 305.0654$ and 305.0665, respectively. Based on QTOF-MS data, retention time, and the previous literature,$^{30,40,41}$ these compounds have been annotated as gallocatechin isomers $\left(\mathrm{C}_{15} \mathrm{H}_{14} \mathrm{O}_{7}\right)$. These compounds were suggested as gallocatechin (transisomer) and epigallocatechin (cis-isomer). Other isomers were found at peaks $20\left([\mathrm{M}-\mathrm{H}]^{-} m / z\right.$ 457.0778) and 24 $\left([\mathrm{M}-\mathrm{H}]^{-} \mathrm{m} / z\right.$ 457.0768). These isomers were annotated as epigallocatechin-3-O-gallate and gallocatechin-3-O-gallate based on the calculated molecular formula $\left(\mathrm{C}_{20} \mathrm{H}_{18} \mathrm{O}_{11}\right)$, $\mathrm{MS}^{2}$ fragments, and retention times position $\left(\mathrm{t}_{\mathrm{R}}=3.61\right.$ and $3.92 \mathrm{~min}$ ) reported in the literature. ${ }^{41}$

\section{Benzophenones}

In this study, two metabolites were annotated from the benzophenones class (peaks 17 and 21). Peak 17 gave ion $[\mathrm{M}-\mathrm{H}]^{-} \mathrm{m} / \mathrm{z} 575.1016$ and molecular formula $\mathrm{C}_{26} \mathrm{H}_{24} \mathrm{O}_{15}$. In the $\mathrm{MS}^{2}$ spectrum was observed the ions fragment values of $\mathrm{m} / \mathrm{z} 423.0760$ [M - H - 152]-, 303.0494 $[\mathrm{M}-\mathrm{H}-272]^{-}$(referring to cross-ring cleavages of the glucose moiety), $285.0258\left[\mathrm{M}-\mathrm{H}-272-\mathrm{H}_{2} \mathrm{O}\right]^{-}$, and neutral loss for the gallic acid unit at $\mathrm{m} / \mathrm{z} 169.0069$ (Figure 2). This compound was annotated as maclurin3- $C$-(2- $O$-galloyl)- $\beta$ - $D$-glucoside from the fragmentation pattern (Figure S2, SI section) reported in the literature. . $^{31,42}$ The other compound was found at peak $\mathbf{2 1}$ that showed an ion $[\mathrm{M}-\mathrm{H}]^{-}$at $m / z, 727.1132$ and the molecular formula $\mathrm{C}_{33} \mathrm{H}_{28} \mathrm{O}_{19}$. The fragment ion of $\mathrm{MS}^{2}$ spectrum was detected at $m / z, 575.1180$ [M $-\mathrm{H}-152]^{-}$caused by loss of galloyl unit. The resulting fragment $m / z 575$ produced product ions at $m / z, 407.0898[\mathrm{M}-\mathrm{H}-152-168]^{-}$indicating the loss of further gallic acid moiety. ${ }^{31}$ Correlating this information with data from the literature, it was possible to identify this compound digalloyl benzophenone derivative known as maclurin-3-C-(2,3-di- $O$-galloyl)- $\beta$ - $D$-glucoside..$^{31,43}$

The benzophenones are intermediates in the biosynthetic pathway of xanthones, and their synthetic derivatives have been used in the composition of sunscreens due to their high capacity to absorb sunlight in the UVB and UVA spectrum region. These compounds are rarely reported in species outside the Clusiaceae and Moraceae family. ${ }^{31,44}$ However, glycosylated benzophenones derivatives were annotated in leaves extracts, ${ }^{45}$ peel and seed ${ }^{31}$ of Mangifera indica L.
(Anacardiaceae family). This is the first study to report these compounds in the specie Spondias purpurea L.

\section{Other metabolites}

Peak 1 had a precursor ion $[\mathrm{M}-\mathrm{H}]^{-}$at $m / z, 207.0141$ and showed $\mathrm{MS}^{2}$ fragments at $m / z, 189.0022\left[\mathrm{M}-\mathrm{H}-\mathrm{H}_{2} \mathrm{O}\right]^{-}$ and $127.0039\left[\mathrm{M}-\mathrm{H}-2 \mathrm{H}_{2} \mathrm{O}-\mathrm{CO}_{2}\right]^{-}$. The compound was annotated as hydroxycitric acid. ${ }^{46}$ Citric acid $\left(\mathrm{C}_{6} \mathrm{H}_{8} \mathrm{O}_{7}\right)$ is proposed for compound 2 with ion $[\mathrm{M}-\mathrm{H}]^{-} \mathrm{m} / \mathrm{z}$ 191.0193, and its $\mathrm{MS}^{2}$ spectrum gave a fragments ion at $\mathrm{m} / \mathrm{z} 111.0097$ $\left[\mathrm{M}-\mathrm{H}-2 \mathrm{H}_{2} \mathrm{O}-\mathrm{CO}_{2}\right]^{-}$and $85.0295[\mathrm{M}-\mathrm{H}-106]^{-.30,31,47,48}$

Peak 14 presented the deprotonated ion $[\mathrm{M}-\mathrm{H}]^{-}$ $m / z 453.1033$ with molecular formula $\mathrm{C}_{20} \mathrm{H}_{22} \mathrm{O}_{12}$ with $\mathrm{MS}^{2}$ fragment at $m / z 313.0612[\mathrm{M}-\mathrm{H}-140]^{-}$referring to a $\mathrm{C}$-glycoside pattern fragmentation was annotated as hydroxymethoxyphenyl- $O$ - $(O$-galloyl $)$-hexose. This compound was previously annotated by Abu-Reidah et al. ${ }^{29}$

The compound 4,9-dihydroxypropiophenone9-O-(6'-O-galloyl)- $\beta$-D-glucopyranoside was annotated in peak 22 with ion $[\mathrm{M}-\mathrm{H}]^{-} m / z 479.1194$ and $\mathrm{MS}^{2}$ fragment ions at $m / z 331.1218[\mathrm{M}-\mathrm{H}-148]^{-}, 271.0358$ $[\mathrm{M}-\mathrm{H}-208]^{-}$and 169.0130 according to Santos et al. ${ }^{24}$ Peaks $7\left(\mathrm{C}_{8} \mathrm{H}_{12} \mathrm{O}_{8}\right), 10\left(\mathrm{C}_{27} \mathrm{H}_{30} \mathrm{O}_{15}\right)$, and $13\left(\mathrm{C}_{37} \mathrm{H}_{43} \mathrm{O}_{22}\right)$ with precursor ions $[\mathrm{M}-\mathrm{H}]^{-}$at $m / z$ 235.0453, 593.1508, 761.1355 , respectively, are not annotated compounds. These compounds showed similar fragment ions in $\mathrm{m} / z, 125$ and 169, indicating the characteristic fragments of galloyl and gallic acid units. Thus, these compounds are possibly derived from gallic acids.

The various groups of polyphenols annotated corroborate with the antioxidant action observed for SBE, since many of these compounds are widely reported in the literature due to their antioxidant potential, which is strongly related to the chemical structure of these metabolites.

Determination of the spectrophotometric profile of SBE and octyl methoxycinnamate

Figure S3 (SI section) shows the scanning profile of the dry extract and octyl methoxycinnamate (OM). OM is one of the most widely used organic UV filter, better known by its commercial name, octinoxate and has been used as positive control in previous studies. ${ }^{49,50}$ It was possible to observe that the extract has a greater absorption in the UVC (100-280 $\mathrm{nm})$ region and the synthetic filter in the UVB region (280-320 nm). However, SBE showed a peak around $280 \mathrm{~nm}$, also demonstrating the energy absorption by the chromophores in the UVB region. According to Wróblewska et al. ${ }^{10}$ extracts containing polyphenols such as flavonoids generally show peaks of 
Table 4. Compounds annotated in SBE using UPLC-QTOF-MS ${ }^{\mathrm{E}}$ in negative mode

\begin{tabular}{|c|c|c|c|c|c|c|c|}
\hline Peak No. & $t_{R} / \min$ & $\begin{array}{c}{[\mathrm{M}-\mathrm{H}]^{-}} \\
\mathrm{m} / \mathrm{z}\end{array}$ & $\begin{array}{l}\text { Product ions } \\
\quad\left(\mathrm{MS}^{2}\right)\end{array}$ & $\begin{array}{c}\text { Molecular } \\
\text { formula }\end{array}$ & Error / ppm & Proposed compound & Reference \\
\hline 1 & 0.89 & 207.0141 & $189.0022 ; 127.0039$ & $\mathrm{C}_{6} \mathrm{H}_{8} \mathrm{O}_{8}$ & 0.0 & hydroxycitric acid & 46 \\
\hline 2 & 1.27 & 191.0193 & $85.0295 ; 111.0097$ & $\mathrm{C}_{6} \mathrm{H}_{8} \mathrm{O}_{7}$ & 0.5 & citric acid & $31,47,48$ \\
\hline 3 & 1.53 & 331.0663 & $\begin{array}{c}271.0451 ; 169.0137 \\
125.0224\end{array}$ & $\mathrm{C}_{13} \mathrm{H}_{16} \mathrm{O}_{10}$ & -0.6 & monogalloyl glucose & 12,31 \\
\hline 4 & 1.76 & 169.0137 & 125.0252 & $\mathrm{C}_{7} \mathrm{H}_{6} \mathrm{O}_{5}$ & 0.0 & gallic acid & 12,30 \\
\hline 5 & 1.84 & 493.1192 & $\begin{array}{l}169.0133 ; 241.0650 \\
271.0373 ; 331.0661\end{array}$ & $\mathrm{C}_{19} \mathrm{H}_{26} \mathrm{O}_{15}$ & -0.2 & monogalloyl di-glucose & 31,35 \\
\hline 6 & 2.05 & 609.1454 & $151.0441 ; 301.0458$ & $\mathrm{C}_{27} \mathrm{H}_{30} \mathrm{O}_{16}$ & -0.3 & rutin & 29 \\
\hline 7 & 2.07 & 235.0453 & - & $\mathrm{C}_{8} \mathrm{H}_{12} \mathrm{O}_{8}$ & -0.4 & n.i. & - \\
\hline 8 & 2.23 & 315.0718 & 153.0193 & $\mathrm{C}_{13} \mathrm{H}_{16} \mathrm{O}_{9}$ & 0.0 & dihydroxybenzoic acid hexoside & 12 \\
\hline 9 & 2.27 & 305.0654 & $\begin{array}{c}219.0548 ; 137.0332 \\
125.0261\end{array}$ & $\mathrm{C}_{15} \mathrm{H}_{14} \mathrm{O}_{7}$ & -0.3 & gallocatechin & $30,40,41$ \\
\hline 10 & 2.31 & 593.1508 & $241.0158 ; 305.0642$ & $\mathrm{C}_{27} \mathrm{H}_{30} \mathrm{O}_{15}$ & 0.3 & n.i. & - \\
\hline 11 & 2.35 & 593.1296 & $\begin{array}{l}441.0632 ; 289.0535 \\
169.0150 ; 125.0174\end{array}$ & $\mathrm{C}_{29} \mathrm{H}_{22} \mathrm{O}_{14}$ & 0.2 & epicatechin-3,5-O-digallate & 40 \\
\hline 12 & 2.43 & 483.0777 & $\begin{array}{l}169.0132 ; 271.0532 \\
313.0634 ; 331.0714\end{array}$ & $\mathrm{C}_{20} \mathrm{H}_{20} \mathrm{O}_{14}$ & 0.4 & digalloyl glucose & 29 \\
\hline 13 & 2.81 & 761.1355 & - & $\mathrm{C}_{37} \mathrm{H}_{30} \mathrm{O}_{18}$ & 0.1 & n.i. & - \\
\hline 14 & 3.10 & 453.1033 & $\begin{array}{c}169.0136 ; 179.0011 \\
313.0612\end{array}$ & $\mathrm{C}_{20} \mathrm{H}_{22} \mathrm{O}_{12}$ & 0.0 & $\begin{array}{l}\text { hydroxymethoxyphenyl- } \\
O \text {-( } O \text {-galloyl }) \text {-hexose }\end{array}$ & 29 \\
\hline 15 & 3.22 & 479.0828 & $\begin{array}{c}271.0215 ; 287.0614 \\
317.0499\end{array}$ & $\mathrm{C}_{21} \mathrm{H}_{20} \mathrm{O}_{13}$ & 0.4 & myricetin 3-O-hexoside & 32,35 \\
\hline 16 & 3.23 & 183.0293 & $124.0053 ; 168.0013$ & $\mathrm{C}_{8} \mathrm{H}_{8} \mathrm{O}_{5}$ & 0.0 & methyl gallate & 29,31 \\
\hline 17 & 3.29 & 575.1016 & $\begin{array}{l}169.0069 ; 285.0258 \\
303.0494 ; 423.0760\end{array}$ & $\mathrm{C}_{26} \mathrm{H}_{24} \mathrm{O}_{15}$ & 1.4 & $\begin{array}{c}\text { maclurin-3-C-(2-O-galloyl)- } \\
\beta \text {-D-glucoside }\end{array}$ & 31,42 \\
\hline 18 & 3.44 & 635.0892 & $\begin{array}{c}\text { 483.0891; 465. 0908; } \\
169.0121\end{array}$ & $\mathrm{C}_{27} \mathrm{H}_{24} \mathrm{O}_{18}$ & 1.3 & trigalloyl hexoside & 29,34 \\
\hline 19 & 3.54 & 305.0665 & $\begin{array}{c}219.0776 ; 137.0319 \\
125.0247\end{array}$ & $\mathrm{C}_{15} \mathrm{H}_{14} \mathrm{O}_{7}$ & 1.3 & epigallocatechin & $30,40,41$ \\
\hline 20 & 3.61 & 457.0778 & $\begin{array}{c}125.0260 ; 169.0125 \\
305.0726\end{array}$ & $\mathrm{C}_{22} \mathrm{H}_{18} \mathrm{O}_{11}$ & -0.7 & epigallocatechin-3-O-gallate & 41 \\
\hline 21 & 3.71 & 727.1132 & $\begin{array}{l}169.0152 ; 303.0419 \\
407.0898 ; 575.1180\end{array}$ & $\mathrm{C}_{33} \mathrm{H}_{28} \mathrm{O}_{19}$ & -2.1 & $\begin{array}{c}\text { maclurin-3-C-(2.3-di- } O \text {-galloyl)- } \\
\beta \text {-D-glucoside }\end{array}$ & 31,43 \\
\hline 22 & 3.76 & 479.1194 & $\begin{array}{c}169.0130 ; 271.0358 \\
331.1218\end{array}$ & $\mathrm{C}_{22} \mathrm{H}_{24} \mathrm{O}_{12}$ & 0.8 & $\begin{array}{c}\text { 4.9-dihydroxypropiophenone- } \\
\text { 9- } O \text {-(6'- } O \text {-galloyl)- } \beta \text {-D- } \\
\text { glucopyranoside }\end{array}$ & 24 \\
\hline 23 & 3.81 & 433.0762 & $\begin{array}{c}151.0077 ; 271.0435 \\
301.0613\end{array}$ & $\mathrm{C}_{20} \mathrm{H}_{17} \mathrm{O}_{11}$ & -2.1 & quercetin pentoside & 12,35 \\
\hline 24 & 3.92 & 457.0768 & $\begin{array}{c}125.0381 ; 169.0128 \\
305.0873\end{array}$ & $\mathrm{C}_{22} \mathrm{H}_{18} \mathrm{O}_{11}$ & -0.7 & gallocatechin-3-O-gallate & 41 \\
\hline 25 & 3.98 & 787.0999 & $169.0118 ; 635.1156$ & $\mathrm{C}_{34} \mathrm{H}_{28} \mathrm{O}_{22}$ & 0.6 & tetra- $O$-galloyl hexoside & 29,34 \\
\hline 26 & 4.15 & 321.0249 & $125.0275 ; 169.0159$ & $\mathrm{C}_{14} \mathrm{H}_{10} \mathrm{O}_{9}$ & 0.6 & digallic acid & 29,32 \\
\hline 27 & 4.24 & 197.0452 & 169.0132 & $\mathrm{C}_{9} \mathrm{H}_{10} \mathrm{O}_{5}$ & 1.0 & ethyl gallate & 31,33 \\
\hline 28 & 4.44 & 481.0990 & 301. 0513; 319.0241 & $\mathrm{C}_{21} \mathrm{H}_{22} \mathrm{O}_{13}$ & 1.7 & ampelopsin glucoside & 29 \\
\hline 29 & 4.52 & 609.0882 & $\begin{array}{l}125.0312 ; 169.0101 \\
305.0735 ; 457.1022\end{array}$ & $\mathrm{C}_{29} \mathrm{H}_{22} \mathrm{O}_{15}$ & -1.6 & epigallocatechin-3,5-O-digallate & 41 \\
\hline 30 & 4.97 & 319.0533 & $\begin{array}{l}125.0441 ; 153.1123 \\
179.0817 ; 193.0112\end{array}$ & $\mathrm{C}_{15} \mathrm{H}_{12} \mathrm{O}_{8}$ & -0.3 & ampelopsin & 29 \\
\hline
\end{tabular}

$\mathrm{t}_{\mathrm{R}}$ : retention time; MS: mass spectrometry; n.i.: not identified. 
absorbing ultraviolet between 240-280 nm. Silva et al. ${ }^{4}$ correlated the photoprotection action in peels extracts from Spondias purpurea L. with its significant content of polyphenolic compounds. Thus, the absorption profile of the extracts of $S$. purpurea $\mathrm{L}$. aerial parts demonstrated the possibility of its use as a sun protection agent.

\section{In vitro UVB photoprotection of the SBE}

Table 5 shows the sun protection of the SBE and the octyl methoxycinnamate. The method described by Mansur et al. ${ }^{21}$ is widely used to measure the in vitro SPF, what proves good correlation with in vivo tests because it relates the absorbance of the substance with the erythematous effect of radiation and the intensity of light at a wavelength from UVB region. ${ }^{51}$ According to Yang et al. ${ }^{52}$ the spectrophotometric screening method described by Mansur et al. ${ }^{21}$ demonstrated a high level of reproducibility and reliability compared to the US FDA-guided in vivo SPF testing method. According to Resolution RDC 30/2012 $2^{53}$ published by ANVISA (National Health Surveillance Agency), the minimum value of sun protection factor (SPF) for products used by the Brazilian population is 6 . The test showed a satisfactory photoprotective activity for the SBE (Table 5). It was possible to observe a better result of SPF than other works in the literature by spectrophotometric method (in vitro): Medina et al. ${ }^{54}$ obtained a SPF of 1.44 for Byrsonima crassifolia leaf extract; de Carvalho et al..$^{55}$ showed SPF equal to $8 \pm 0.31$ for hydroethanolic extract of Pterodon emarginatus, fruit; and Lima-Saraiva et al..$^{56}$ found SPF of $6.27 \pm 0.69$ at $100 \mathrm{mg} \mathrm{L}^{-1}$ for hydroethanolic extract (aerial parts) of Schinopsis brasiliensis Engl. Therefore, S. purpurea L. stem bark extract could be considered a promising active ingredient, as it presented high sun protection factors at low dilution.

Table 5. Sun protection factor of SBE, octyl methoxycinnamate (OM) and formulations containing SBE and OM

\begin{tabular}{lcc}
\hline Sample/formulations & SPF $\left(0.2 \mathrm{mg} \mathrm{mL}^{-1}\right)$ & $\mathrm{SPF}\left(2.0 \mathrm{mg} \mathrm{mL}^{-1}\right)$ \\
\hline $\mathrm{SBE}$ & $14.37 \pm 0.009^{\mathrm{a}}$ & $26.16 \pm 0.013^{\mathrm{a}}$ \\
$\mathrm{OM}$ & $14.19 \pm 0.010^{\mathrm{b}}$ & $21.84 \pm 0.038^{\mathrm{b}}$ \\
$\mathrm{FBE}_{0.2}$ & $0.495 \pm 0.001^{\mathrm{h}}$ & $2.29 \pm 0.098^{\mathrm{h}}$ \\
$\mathrm{FBE}_{2.5}$ & $0.702 \pm 0.002^{\mathrm{g}}$ & $6.89 \pm 0.006^{\mathrm{g}}$ \\
$\mathrm{FBE}_{5}$ & $1.39 \pm 0.008^{\mathrm{f}}$ & $10.15 \pm 0.005^{\mathrm{f}}$ \\
$\mathrm{FBE}_{10}$ & $1.58 \pm 0.006^{\mathrm{e}}$ & $10.84 \pm 0.012^{\mathrm{e}}$ \\
$\mathrm{FBOM}_{7.5}$ & $2.15 \pm 0.012^{\mathrm{d}}$ & $17.16 \pm 0.005^{\mathrm{d}}$ \\
$\mathrm{FBE}_{10} \mathrm{OM}_{7.5}$ & $2.27 \pm 0.004^{\mathrm{c}}$ & $15.87 \pm 0.010^{\mathrm{c}}$ \\
\hline
\end{tabular}

Values expressed are means \pm standard deviation; $\mathrm{n}=3$. Different letters in the same column indicate differences in measurements $(p<0.05)$. SPF: sun protection factor; FB: base formulation; FBE: base formulation with extract; SBE: stem bark extract; OM: octyl methoxycinnamate.
According to the chemical profile of SBE (Table 4) the main compounds that can be associated with the highest SPF values are flavonoids, benzophenones, and acid gallic derivatives. The flavonoids such as quercetin, myricetin, catechin, epicatechin, and their derivatives, have the potent antioxidant capacity, widely reported in the literature. ${ }^{8,57-59}$ These substances have conjugated bonds and chemical groups that absorb UV radiation at different wavelengths. ${ }^{60}$ Adding to this, we still have benzophenones, which are classes of metabolites that have powerful antioxidant and photoprotective action. ${ }^{31}$ Hwang et al. ${ }^{61}$ showed the protective effects of acid gallic against photoaging caused by UVB radiation in vitro and in vivo. Besides, when associated with synthetic filters, these substances can help stabilize the characteristics of conventional UV filters during exposure to solar radiation..$^{60}$

Preparation of a cosmetic formulation and in vitro SPF determination

SPF is one of the universally accepted parameters used to evaluate the efficacy of a sunscreen. ${ }^{62}$ In the present study, formulations with SBE were produced in the concentrations 0.2 , and $2.0 \mathrm{mg} \mathrm{mL}^{-1}$, and SPF values of the formulations were described in Table 5. The test allowed verifying that the photoprotection activity is proportional to the amount of extract added to the formulation. The results obtained for the $0.2 \mathrm{mg} \mathrm{mL}^{-1}$ concentration was less significant, showing the dependence of the sun protection factor with the increase of the photoprotective agent concentration. Formulations containing only extract showed an increase in the SPF value as the incorporation of phenolic compounds of SBE of S. purpurea L. increased. Therefore, it was possible to observe that the concentration of $2.0 \mathrm{mg} \mathrm{mL}^{-1}$ extract was able to absorb the UVB radiation. The formulations $\mathrm{FBE}_{2.5}, \mathrm{FBE}_{5}$, and $\mathrm{FBE}_{10}$ were found to possess SPF values of $6.89 \pm 0.006,10.15 \pm$ $0.005,10.84 \pm 0.012$, respectively. Silva et $a .^{4}{ }^{4}$ in a study with Spondias purpurea L. fruits peels, obtained SPF of 0.70 and 0.79 , respectively, in a formulation with $10 \%$ of hydroethanolic crude extract at a dilution of $2.0 \mathrm{mg} \mathrm{mL}^{-1}$, demonstrating a superior photoprotective activity of the SBE at the same concentrations (Table 5).

However, the SPF values for formulations with extract were lower than the control $\left(\mathrm{FBOM}_{7.5}\right)$ and the analysis of the synergistic effect $\left(\mathrm{FBE}_{10} \mathrm{OM}_{7.5}\right)$. Thus, no synergistic effect was observed between the extract and the sunscreen. The SPF obtained was attributed to the absorptive and photoprotective characteristics of octyl methoxycinnamate. Although not contributing with the in vitro SPF, SBE presents phenolic compounds that could 
act preventing UV-induced damage by other mechanisms, e.g., capturing and inactivating ROS. ${ }^{63}$ Many factors may interfere with the determination of SPF, as the type of emulsion, the concentration of the sunscreen, interactions of the formulation components, $\mathrm{pH}$, rheological properties, or other factors that may increase or decrease the UVB absorption of the photoprotective substance. ${ }^{64}$ Thus, the phenolic antioxidants of $S$. purpurea stem bark can be added in solar filters to complement UV filter photoprotection, reducing free radical damage generated after sun exposure and also to stabilize UV chemical filters. ${ }^{10,50,62}$

The results of this research are in accordance with the increased interest in the use of plants to treat or prevent diseases and may contribute to the development and diversification of new sunscreen products by two different mechanisms: absorption of UV radiation and antioxidant activity. ${ }^{60}$

\section{Conclusions}

In this study, the stem bark extract of Spondias purpurea L., showed high potential as antioxidant and photoprotective agents, corroborating with the elevated value of phenolic content and chemical profile obtained by UPLC-QTOF-MS ${ }^{2}$. A total of thirty compounds, including five simple phenolic acids, five hydrolysable tannins, eleven flavonoids and derivatives, two benzophenones, and four simple acids glycosylated were annotated. However, three compounds could not be annotated. These results led to the preparation of sunscreen formulations, with the same plant extract, and in combination with commercial UV filter. The SBE individually showed higher SPF values. However, these formulations, containing a sunscreen base and SBE, showed slightly lower SPF values compared to the commercial UV filter formulation. These results demonstrate that there was no synergic action between components of formulations. Due to its rich composition in phenolic substances and its positive outcomes for antioxidant activity, SBE of Spondias purpurea L. can provide a promising source of photoprotective agents for new phytocosmetic formulations.

\section{Supplementary Information}

Supplementary information (Figures S1-S3) is available free of charge at http://jbcs.sbq.org.br as PDF file.

\section{Acknowledgments}

This study was financed in part by the Coordenação de Aperfeiçoamento de Pessoal de Nível Superior - Brazil (CAPES) - Finance Code 001 (PROEX
23038.000509/2020-82). The authors thank Embrapa Tropical Agroindustry. The corresponding author thanks CNPq for the research grant (N.M.P.S.R-No. 307837/2017-3) and Fundação Cearense de Apoio ao Desenvolvimento Científico e Tecnológico (FUNCAP) for the support.

\section{Author Contributions}

Francisco Alessandro M. Rodrigues was responsible for conceptualization, data curation, formal analysis, investigation, methodology, writing-review and editing, writing-original draft; Priscylla S. Giffony for data curation, formal analysis, methodology, writing-review and editing; Sarah B. F. dos Santos for data curation, formal analysis; Jhonyson A. C. Guedes for data curation, methodology; Maria Elenir N. P. Ribeiro for resources, writing-original draft, writing-review and editing; Tamara G. de Araújo for formal analysis, methodology; Larissa M. R. da Silva for formal analysis, methodology; Guilherme J. Zocolo for formal analysis, methodology, supervision, writing-review and editing; Nágila M. P. S. Ricardo for conceptualization, funding acquisition, investigation, project administration, resources, supervision, writing-original draft, writingreview and editing.

\section{References}

1. Ferlay, J.; Colombet, M.; Soerjomataram, I.; Mathers, C.; Parkin, D. M.; Piñeros, M.; Znaor, A.; Bray, F.; Int. J. Cancer 2019, 144, 1941.

2. Lacatusu, I.; Arsenie, L. V.; Badea, G.; Popa, O.; Oprea, O.; Badea, N.; Ind. Crops Prod. 2018, 123, 424.

3. Dario, M. F.; Oliveira, F. F.; Marins, D. S. S.; Baby, A. R.; Velasco, M. V. R.; Löbenberg, R.; Bou-Chacra, N. A.; Ind. Crops Prod. 2018, 112, 305.

4. Silva, R. V.; Costa, S. C. C.; Branco, C. R. C.; Branco, A.; Ind. Crops Prod. 2016, 83, 509.

5. Bazylko, A.; Borzym, J.; Parzonko, A.; J. Photochem. Photobiol., B 2015, 149, 189.

6. Duque, L.; Bravo, K.; Osorio, E.; Ind. Crops Prod. 2017, 97, 431.

7. Lin, C.; Lee, M.; Chi, M.; Chen, C.; Lin, H.; ACS Omega 2019 , 4, 1801.

8. Santhanam, R. K.; Akhtar, M. T.; Ahmad, S.; Abas, F.; Ismail, I. S.; Rukayadi, Y.; Shaari, K.; Ind. Crops Prod. 2017, 96, 165.

9. Silva, A. C. P.; Paiva, J. P.; Diniz, R. R.; Anjos, V. M.; Silva, A. B. S. M.; Pinto, A. V.; Santos, E. P.; Leitão, A. C.; Cabral, L. M.; Rodrigues, C. R.; Pádula, M.; Santos, B. A. M. C.; J. Photochem. Photobiol., B 2015, 193, 162. 
10. Wróblewska, K. B.; Baby, A. R.; Guaratini, M. T. G.; Moreno, P. R. H.; Ind. Crops Prod. 2019, 130, 208.

11. Rasera, G. B.; Hilkner, M. H.; Alencar, S. M.; Castro, R. J. S.; Ind. Crops Prod. 2019, 135, 294.

12. Engels, C.; Gräter, D.; Esquivel, P.; Jiménez, V. M.; Gänzle, M. G.; Schieber, A.; Food Res. Int. 2012, 46, 557.

13. Muñoz-Ramírez, A.; Torrent-Farías, C.; Mascayano-Collado, C.; Urzúa-Moll, A.; Phytochemistry 2020, 174, 112359.

14. Bicas, J. L.; Molina, G.; Dionísio, A. P.; Barros, F. F. C.; Wagner, R.; Maróstica, M. R.; Pastore, G. M.; Food Res. Int. 2011, 44, 1843.

15. Vargas-Simón, G. In Exotic Fruits, $1^{\text {st }}$ ed.; Rodrigues, S.; Silva, E. O.; Brito, E. S., eds.; Academic Press: Cambridge, USA, 2018.

16. Singleton, V. L.; Rossi, J. A.; Am. J. Enol. Vitic. 1965, 16, 144.

17. Lin, J.; Tang, C.; Food Chem. 2007, 101, 140.

18. Chew, Y. L.; Lim, Y. Y.; Omar, M.; Khoo, K. S.; LWT-Food Sci. Technol. 2008, 41, 1067.

19. Masslynx v.41 SCN719; Water Corporation, Milford, USA, 2009.

20. Munhoz, V. M.; Lonni, A. A. S. G.; Mello, J. C. P.; Lopes, G. C.; Rev. Cienc. Farm. Basica Apl. 2012, 33, 225.

21. Mansur, J. S.; Breder, M. N. R.; Mansur, M. C. A.; Azulay, R. D.; An. Bras. Dermatol. 1986, 61, 121.

22. Minitab v.19.2020.1; Minitab LCC, State College, Pennsylvania, USA, 2020.

23. Remila, S.; Atmani-Kilani, D.; Delemasure, S.; Connat, J. L.; Azib, L.; Richard, T.; Atmani, D.; Eur. J. Integr. Med. 2015, 7, 274.

24. Santos, C. C. S.; Masullo, M.; Cerulli, A.; Mari, A.; Estevam, C. D. S.; Pizza, C.; Piacente, S.; Phytochemistry 2017, 140, 45.

25. Tiburski, J. H.; Rosenthal, A.; Deliza, R.; Godoy, R. L. O.; Pacheco, S.; Food Res. Int. 2011, 44, 2326.

26. Villa-Hernández, J. M.; Mendoza-Cardoso, G.; MendozaEspinoza, J. A.; Vela-Hinojosa, C.; León-Sánchez, F. D.; Rivera-Cabrera, F.; Alia-Tejacal, I.; Pérez-Flores, L. J.; J. Food Sci. 2017, 82, 2576.

27. Abeywickrama, G.; Debnath, S. C.; Ambigaipalan, P.; Shahidi, F.; J. Agric. Food Chem. 2016, 64, 9342.

28. Rodrigues, F. A. M.: Filmes e Revestimentos Ativos à Base de Amido e Bioativos de Spondias purpurea para Aplicação em Manga Minimamente Processada; MSc dissertation, Federal University of Ceará, Fortaleza, Brazil, 2018, available at http:// www.repositorio.ufc.br/bitstream/riufc/39134/5/2018_dis_ famrodrigues.pdf, accessed in April 2021.

29. Abu-Reidah, I. M.; Ali-Shtayeh, M. S.; Jamous, R. M.; ArráezRomán, D.; Segura-Carretero, A.; Food Chem. 2015, 166, 179.

30. Castro, C. B.; Luz, L. R.; Guedes, J. A. C.; Porto, D. D.; Silva, M. F. S.; Silva, G. S.; Ribeiro, P. R. V.; Canuto, K. M.; Brito, E. S.; Zampieri, D. S.; Pessoa, C. O.; Zocolo, G. J.; J. Braz. Chem. Soc. 2020, 31, 775.
31. Dorta, E.; González, M.; Lobo, M. G.; Sánchez-Moreno, C.; Ancos, B.; Food Res. Int. 2014, 57, 51.

32. Erşan, S.; Üstündağ, Ö. G.; Carle, R.; Schweiggert, R. F.; J. Agric. Food Chem. 2016, 64, 5334.

33. Shaheen, N.; Lu, Y.; Geng, P.; Shao, Q.; Wei, Y.; J. Chromatogr. B: Anal. Technol. Biomed. Life Sci. 2017, 1046, 211.

34. Muccilli, V.; Cardullo, N.; Spatafora, C.; Cunsolo, V.; Tringali, C.; Food Chem. 2017, 215, 50.

35. Cunha, A. G.; Brito, E. S.; Moura, C. F. H.; Ribeiro, P. R. V.; Miranda, M. R. A.; J. Chromatogr. B: Anal. Technol. Biomed. Life Sci. 2017, 1051, 24.

36. Silva, A. R. A.; Morais, S. M.; Marques, M. M. M.; Oliveira, D. F.; Barros, C. C.; Almeida, R. R.; Vieira, I. G. P.; Guedes, M. I. F.; Pharm. Biol. 2012, 50, 740.

37. Li, Z.; Guo, H.; Xu, W.; Ge, J.; Li, X.; Alimu, M.; He, D.; J. Chromatogr. Sci. 2016, 54, 805.

38. Brito, A.; Ramirez, J. E.; Areche, C.; Sepúlveda, B.; Simirgiotis, M. J.; Molecules 2014, 19, 17400.

39. Woo, H.; Kanga, H.; Nguyena, T. T. H.; Kim, G.; Kim, Y.; Park, J.; Kime, D.; Cha, J.; Moo, Y.; Mam, S.; Xia, Y.; Kimura, A.; Kim, D.; Enzyme Microb. Technol. 2012, 51, 311.

40. Shoko, T.; Maharaj, V. J.; Naidoo, D.; Tselanyane, M.; Nthambeleni, R.; Khorombi, E.; Apostolides, Z.; BMC Complementary Altern. Med. 2018, 18, 54.

41. Wang, D.; Lu, J.; Miao, A.; Xie, Z.; Yang, D.; J. Food Compos. Anal. 2008, 21, 361.

42. Galvão, W. R. A.; Braz Filho, R.; Canuto, K. M.; Ribeiro, P. R. V.; Campos, A. R.; Moreira, A. C. O. M.; Silva, S. O.; Mesquita Filho, F. A.; Santos S. A. A. R.; Melo Jr., J. M. A.; Gonçalves, N. G. G.; Fonseca, S. G. C.; Bandeira, M. A. M.; J. Ethnopharmacol. 2018, 222, 177.

43. Barreto, J. C.; Trevisan, M. T. S.; Hull, W. E.; Erben, G.; Brito, E. S.; Pfundstein, B.; Owen, R. W.; J. Agric. Food Chem. 2008, $56,5599$.

44. Marto, J.; Gouveia, L. F.; Chiari, B. G.; Paiva, A.; Isaac, V.; Pinto, P.; Ribeiro, H. M.; Ind. Crops Prod. 2016, 80, 93.

45. Pan, J.; Yi, X.; Zhang, S.; Cheng, J.; Wang, Y.; Liu, C.; He, X.; Ind. Crops Prod. 2018, 111, 400.

46. Pandey, R.; Chandra, P.; Kumar, B.; Srivastva, M.; Aravind, A. P. A.; Shameer, P. S.; Rameshkumar, K. B.; Ind. Crops Prod. 2015, 77, 861.

47. Carvalho-Silva, L. B.; Dionísio, A. P.; Pereira, A. C. S.; Wurlitzer, N. J.; Brito, E. S.; Bataglion, G. A.; Brasil, I. M.; Eberlin, M. N.; Liu, R. H.; LWT-Food Sci. Technol. 2014, 59, 1319.

48. Luz, L. R.; Porto, D. D.; Castro, C. B.; Silva, M. F. S.; Alves Filho, E. G.; Canuto, K. M.; Brito, E. S.; Becker, H.; Pessoa, C. O.; Zocolo, G. J.; J. Chromatogr. B: Anal. Technol. Biomed. Life Sci. 2018, 1099, 97.

49. Almeida, W. A. S.; Antunes, A. S.; Penido, R. G.; Correa, H. S. G.; Nascimento, A. M.; Andrade, Â. L.; Santos, V. R.; Cazati, 
T.; Amparo, T. R.; Souza, G. H. B.; Freitas, K. M.; Santos, O. D. H.; Sousa, L. R. D.; Santos, V. M. R.; Rev. Bras. Farmacogn. 2019, 29, 373.

50. Kanlayavattanakul, M.; Kasikawatana, N.; Lourith, N.; $J$ Cosmet. Sci. 2016, 67, 167.

51. Violante, I. M. P.; Souza, I. M.; Venturini, C. L.; Ramalho, A. F. S.; Santos, R. A. N.; Ferrari, M.; Rev. Bras. Farmacogn. 2009, $19,452$.

52. Yang, S. I.; Liu, S.; Brooks, G. J.; Lanctot, Y.; Gruber, J. V.; J. Cosmet. Dermatol. 2018, 17, 518.

53. Agência Nacional de Vigilância Sanitária (ANVISA): Resolução RDC No. 30, de 1 de junho de 2012, Aprova o Regulamento Técnico Mercosul sobre Protetores Solares em Cosméticos e dá outras Providências, available at http://bvsms.saude.gov.br/bvs/ saudelegis/anvisa/2012/rdc0030_01_06_2012.html, accessed in May 2021.

54. Medina, C. O.; Louchard, B. O.; Gonçalves, T.; Rev. Cienc. Farm. Basica Apl. 2015, 36, 391.

55. de Carvalho, W. L.; Moreira, L. C.; Valadares, M. C.; Diniz, D. G.; Bara, M. T.; Pharmacogn. Mag. 2019, 15, 176.

56. Lima-Saraiva, S. R. G.; Oliveira, F. G. S.; Oliveira Jr., R. G.; Araújo, C. S.; Oliveira, A. P.; Pacheco, A. G. M.; Rolim, L. A.; Amorim, E. L. C.; César, F. C. S.; Almeida, J. R. G. S.; Hindawi 2017, 1713921 .
57. Baloglu, M. C.; Llorent-Martínez, E. J.; Aumeeruddy, M. Z.; Mahomoodally, M. F.; Altunoglu, Y. C.; Ustaoglu, B.; Ocal, M.; Bene, S. G. K.; Sinan, K. I.; Zengin, G.; Ind. Crops Prod. 2019, 134, 33.

58. Guitard, R.; Paul, J. F.; Nardello-Rataj, V.; Aubry, J. M.; Food Chem. 2016, 213, 284.

59. Lesjak, M.; Beara, I.; Simin, N.; Pintać, D.; Majkić, T.; Bekvalac, T.; Orčić, D.; Mimica-Dukić, N.; J. Funct. Foods 2018, 40, 68 .

60. Mota, M. D.; Boa Morte, A. N.; Silva, L. C. R. C.; Chinalia, F. A.; J. Photochem. Photobiol., B 2020, 205, 111837.

61. Hwang, E.; Park, S.; Lee, H. J.; Lee, T. Y.; Sun, Z.; Yi, T. H.; Phytother. Res. 2014, 28, 1778.

62. Chiari-Andréo, B. G.; Almeida, F. B.; Yamasaki, P. R.; Santos, J. L.; Corrêa, M. A.; Chin, C. M.; Isaac, V. L. B.; Rodriguésia 2020, 71, e03072018.

63. Mansur, M. C. P. P. R.; Leitão, S. G.; Cerqueira-Coutinho, C.; Vermelho, A. B.; Silva, R. S.; Presgrave, O. A. F.; Leitão, A. A. L.; Leitão, G. G.; Ricci-Júnior, E.; Santos, E. P.; Rev. Bras. Farmacogn. 2016, 26, 251.

64. Dutra, E. A.; Oliveira, D. A. G. C.; Kedor-Hackmann, E. R. M.; Santoro, M. I. R. M.; Braz. J. Pharm. Sci. 2004, 40, 381.

Submitted: October 23, 2020

Published online: June 7, 2021 